\title{
Accessory Chromosomes in Norwegian Populations of Paris quadrifolia $\mathrm{L}$.
}

\author{
Dag Bjerketvedt and Morten Motzfeldt Laane \\ Institute of General Genetics and Botanical Laboratory, \\ University of Oslo, Blindern, Oslo 3, Norway
}

Received May 27, 1980

Accessory chromosomes (ref. Håkansson 1945, Müntzing 1945, Müntzing 1974) are now known from numerous plant species. In 1964 Battaglia published a list of 160 species of higher plants with occurrence of such chromosomes, and only a few years later the number had increased to about 590 species belonging to 219 genera (Jones 1975).

Accessory chromosomes are not necessary for the life of the individual and may be present in only certain tissues. They are further subinert, having weaksometimes distinct genetic effects. These chromosomes may also reduce the fertility (Battaglia 1964, Rees 1974) and sometimes increase the frequence and distribution of chiasmata (Vosa and Barlow 1972, Müntzing 1974, Rees 1974, - see also Dyer 1979).

It is frequently found that they are heterochromatic and are often of considerably smaller size than the members of the regular chromosome complement.

The origin and formation of accessory chromosomes are largely unknown. Recently, new theories have been proposed involving a possible origin of accessory chromosomes by breaks in meta- and acrocentric chromosomes together with centric fusion (Jones 1978).

The complex problems involved with accessory chromosome formation and behaviour are naturally most favourably analyzed in plant species with very large chromosomes. In the tribe Paridae of the family Liliaceae the genera Trillium and Paris have almost the largest chromosomes known in the plant kingdom (Huskins and Wilson 1938, Geitler 1937, 1938). Accessory chromosomes have previously been reported from $P$. polyphylla and $P$. tetraphylla. We report such chromosomes in a third species $P$. quadrifolia $L$. This is widely distributed all over the country from the southernmost parts of Norway to the arctic northern areas, being rare on the western coast, but may occur in the central mountain area up to $1200 \mathrm{~m}$ above sea level.

\section{Materials and methods}

Populations from 26 different localities (Table 1, Fig. 1) were analyzed and grown in green-houses at the Botanical Laboratory, University of Oslo. More than 10 different specimens were studied from each population. Totally about 800 specimens were examined. 
Root-tips were pre-treated in $0,2 \%$ colchicine in distilled water for about 3 hours at $20^{\circ} \mathrm{C}$, then fixed in acetic-ethanol for about 48 hours. The specimens were then preserved in $70 \%$ ethanol until examination.

Table 1. Survey of material examined. Chromosome accounts are added.

Paris quadrifolia $\mathrm{L}$.

\begin{tabular}{|c|c|c|c|c|}
\hline $\begin{array}{l}\text { Popula- } \\
\text { tion no. }\end{array}$ & Locality & Habitat & $\begin{array}{l}\text { Chromosome } \\
\text { no. }\end{array}$ & $\begin{array}{c}\text { No. of } \\
\text { examined } \\
\text { specimens }\end{array}$ \\
\hline P1 & Kirkenes, Finnmark & Birch forest, course of brook & $2 n=20$ & 12 \\
\hline $\mathrm{P} 2$ & $\begin{array}{l}\text { Talvik, Alta, } \\
\text { Finnmark }\end{array}$ & Pine-alder forest, moist soil & $2 n=20$ & 12 \\
\hline P3 & Tromsø, Troms & Birch forest among small ferns & $2 n=20+10$ acc. & 200 \\
\hline P4 & $\begin{array}{l}\text { Søreide, Gloppen, } \\
\text { Sogn \& Fjordande }\end{array}$ & Deciduous forest, moist, sunny & $2 n=20$ & 13 \\
\hline P5 & Voss, Hordaland & Spruce forest, shady & $2 n=20$ & 16 \\
\hline P6 & Voss, Hordaland & $\begin{array}{l}\text { Deciduous forest, moist soil, } \\
\text { shady }\end{array}$ & $2 n=20$ & 18 \\
\hline P7 & Bergen, Hordaland & $\begin{array}{l}\text { Deciduous forest, moist soil, } \\
\text { shady }\end{array}$ & $2 n=20$ & 31 \\
\hline P8 & Fana, Hordaland & $\begin{array}{l}\text { Deciduous forest, moist soil, } \\
\text { shady }\end{array}$ & $2 n=20$ & 12 \\
\hline P9 & Stord, Hordaland & $\begin{array}{l}\text { Deciduous forest, moist soil, } \\
\text { shady }\end{array}$ & $2 n=20$ & 30 \\
\hline P10 & Røldal, Hordaland & $\begin{array}{l}\text { Among tall herbs, moist soil, } \\
\text { shady, stony place } 700 \mathrm{~m}\end{array}$ & $2 n=20$ & 11 \\
\hline P11 & Farsund, Vest-Agder & Deciduous forest, moist soil & $2 \mathrm{n}=20$ & 11 \\
\hline P12 & Arendal, Aust-Agder & Wet Picea forest & $2 n=20$ & 14 \\
\hline P13 & Lillesand, Aust-Agder & Meadow on limestone & $2 n=20$ & 14 \\
\hline P14 & Gjerstad, Aust-Agder & $\begin{array}{l}\text { Picea forest with herbs (Melico- } \\
\text { Picetum) }\end{array}$ & $2 n=20$ & 12 \\
\hline P15 & Nome, Telemark & Mixed forest, dry, sunny place & $2 n=20$ & 20 \\
\hline P16 & Nome, Telemark & $\begin{array}{l}\text { Picea forest with herbs (Melico- } \\
\text { Picetum) }\end{array}$ & $2 n=20$ & 30 \\
\hline P17 & Siljan, Telemark & $\begin{array}{l}\text { Picea forest with herbs (Melico- } \\
\text { Picetum), shady place, moist soil }\end{array}$ & $2 n=20+1$ acc. & 100 \\
\hline P18 & Skien, Telemark & $\begin{array}{l}\text { Picea forest with herbs (Melico- } \\
\text { Picetum), shay place, moist soil }\end{array}$ & $2 n=20$ & 25 \\
\hline P19 & Skien, Telemark & $\begin{array}{l}\text { Picea forest with herbs (Melico- } \\
\text { Picetum) shady place, moist soil }\end{array}$ & $2 n=20+2$ acc. & 100 \\
\hline $\mathbf{P} 20$ & Rygge, Ostfold & $\begin{array}{l}\text { Deciduous forest, shady, moist } \\
\text { soil }\end{array}$ & $2 n=20$ & 25 \\
\hline $\mathbf{P} 21-23$ & $\begin{array}{l}\text { Oslo, different } \\
\text { localities }\end{array}$ & Deciduous forest, shady & $2 n=20$ & $20-20-15$ \\
\hline $\mathbf{P} 24$ & Blankvann, Oslo & $\begin{array}{l}\text { Marsh, soil containing lime, } \\
\text { moist and exposed to sun }\end{array}$ & $2 n=20$ & 15 \\
\hline P25 & Svartor, Oslo & On limestone, dry, exposed to sun & $2 \mathrm{n}=20$ & 15 \\
\hline P26 & Hønefoss, Buskerud & Deciduous forest, shady place & $2 \mathrm{n}=20$ & 14 \\
\hline
\end{tabular}

The material was squashed in $45 \%$ acetic acid and stained in $2 \%$ orcein. The preparations were then mounted in Euparal.

Meiotic cells were simply dissected out by aid of two needles, fixed in $45 \%$ acetic acid on the slide and stained by adding a drop of aceto-orcein. The preparations were mounted in Euparal. 
Microphotos were made by a Zeiss Photomicroscope II, using an oil immersion planapochromatic lens 63/1, 40 and Kodak Plus X (22 ${ }^{\circ}$ DIN) film.

\section{Observations and discussion}

All populations of Paris quadrifolia examined were on the "tetraploid" level with the somatic chromosome number 20 (ref. Table 1).
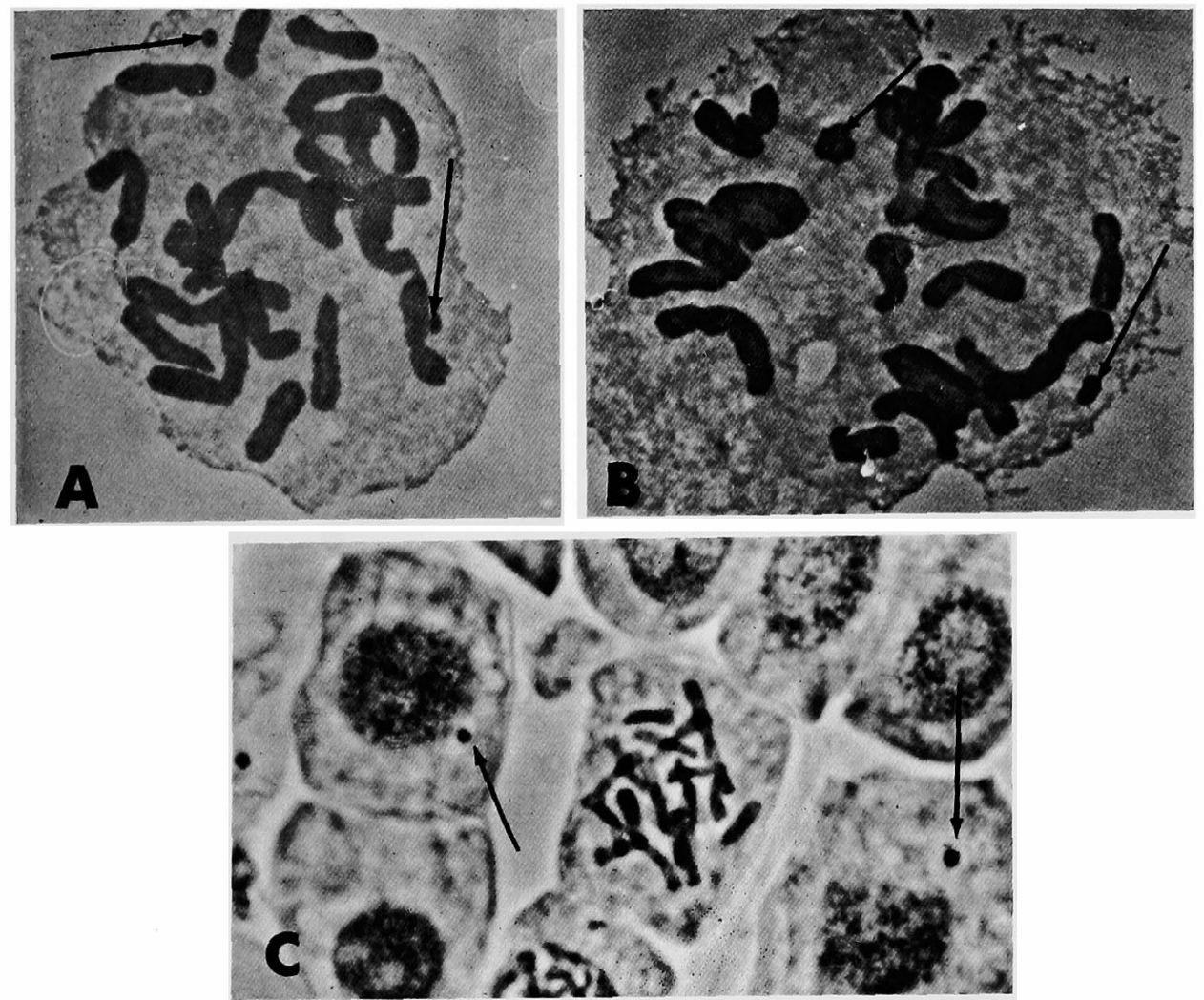

Fig. 1. Accessory chromosomes in Pop. 19 (A, B) and Pop. 17 (C) of Paris quadrifolia L. (A, B) show second meiotic division, $(C)$ shows mitosis and interphase in root-tip cells.

The chromosomes may be arranged in five groups of four, reflecting an allotetraploid origin. Especially in the short arms the four members of each type of chromosomes differ in the manner expected for an allotetraploid. In principle all populations contained 4 large, metacentrics (A-group) +4 large submetacentrics (B-group) +4 medium submetacentrics (C-group) +4 medium acrocentrics (Dgroup) +4 medium-subtelocentrics (E-group) + accessories (f):

$$
4 \mathrm{~L}_{\mathrm{m}}+4 \mathrm{~L}_{\mathrm{sm}}+4 \mathrm{M}_{\mathrm{sm}}+4 \mathrm{M}_{\mathrm{a}}+4 \mathrm{M}_{\mathrm{st}}+(\text { acc. })
$$
(A)
(B)
(C)
(D)
(E)

The most distinct differences inside the groups are in the short arms of the Egroup where two chromosomes usually lack the NOR-region. 
There are characteristic variations in karyotypes between different populations, due to presence of unequal long and/or short arms inside the groups. These are considered mostly to be due to gross structural rearrangements.

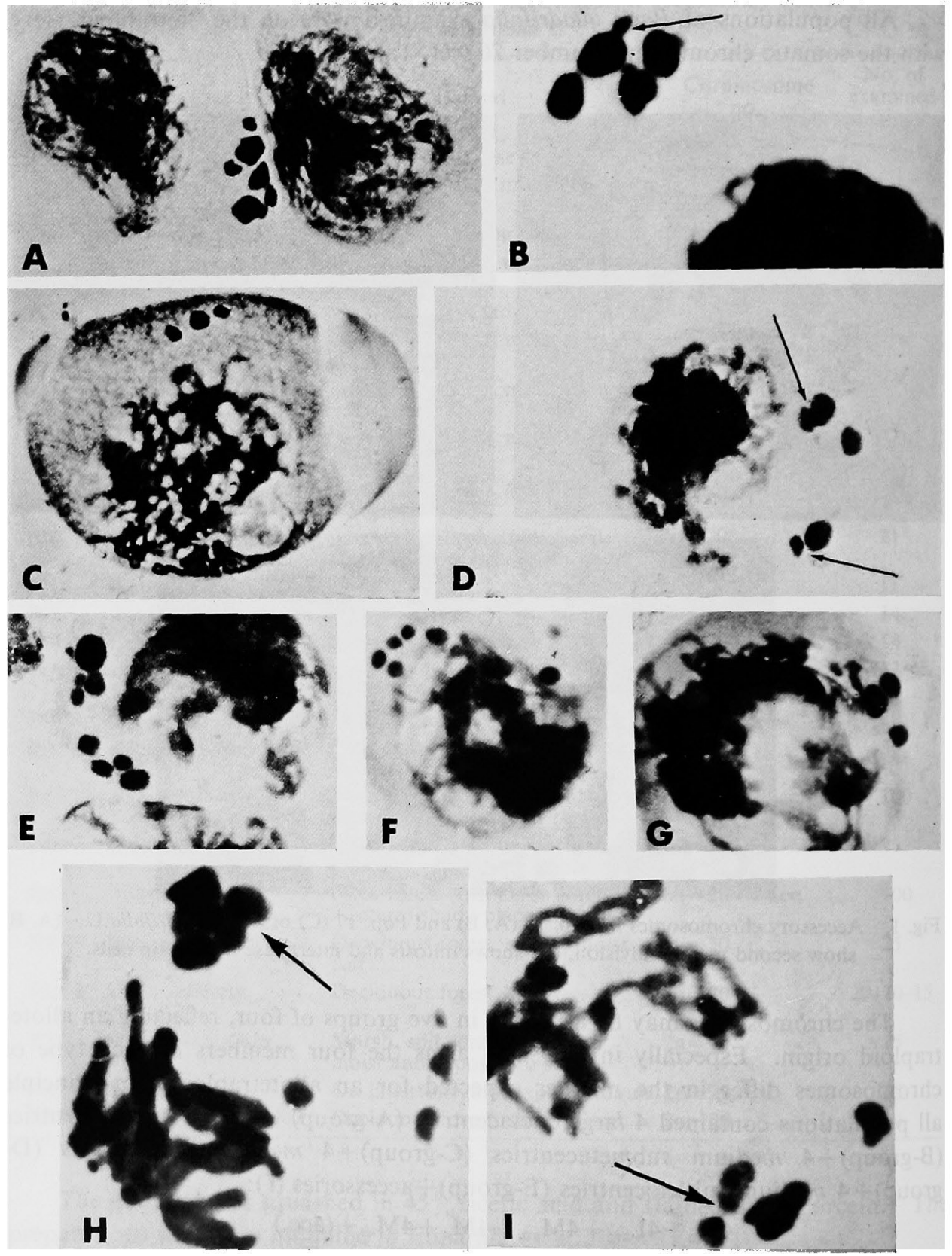

Fig. 2. Accessory chromosomes in pollen mother cells of Pop. 3 of Paris quadrifolia L. Note variations in numbers and size. Arrows point at probable constrictions. The numbers varied mostly between $3(\mathrm{C}, \mathrm{D}, \mathrm{H})$ and $9(\mathrm{E})$. 


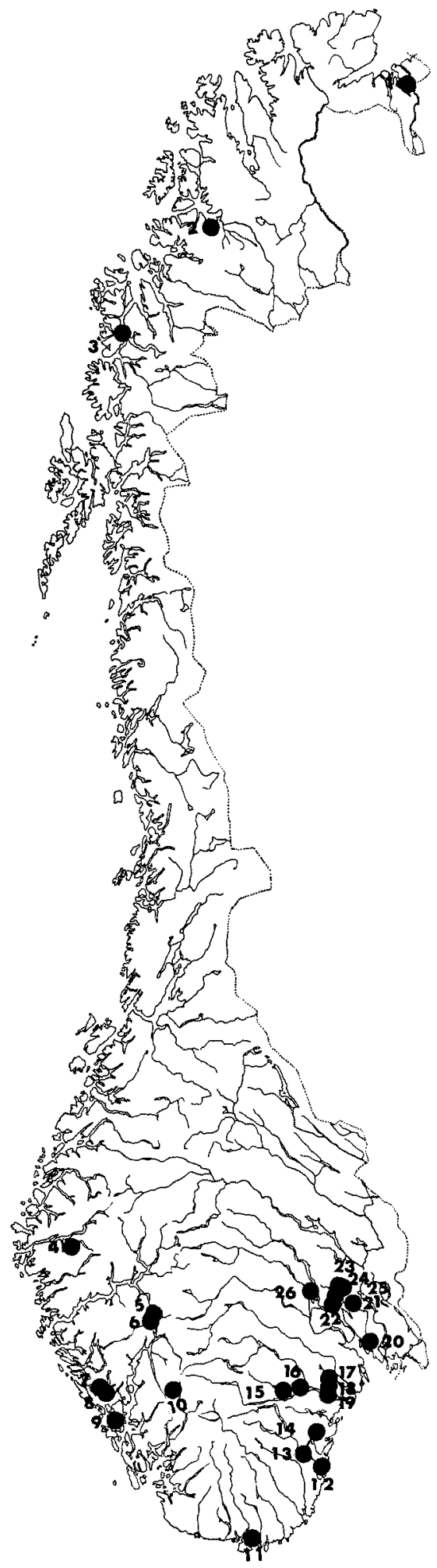

Fig. 3. Map of Norway showing the distribution of the examined populations. 
The average length of chromosome arms in different groups were calculated by Darlington (1941) as:
(A) $9.5+9$
(B) $7.5+5$
(C) $5.5+3.5$
(D) $9+2.5$
(for $4 \mathrm{chr}$.)
(4 chr.)
(4 chr.)
(4 chr.)
(E) $9+0.5$
(4 chr.)

These values in $\mu \mathrm{m}$ appears to represent the usual situation in the Norwegian Paris karyotypes. However, about $20 \%$ of the Norwegian material shows karyotype deviations. Only one extreme example will be mentioned:

Population (12):
(A) $0.2+7$ and
$9.5+9$
( $3 \mathrm{chr}$.)
(one chr.)
(B) $7.5+5$
(4 chr.)
(D) 0
and $9+2.5$
(E) $9+0.5$
(missing)
(3 chr.)
(4 chr.)
(C) $5.5+3.5$
(4 chr.)

Table 2. Number of accessory chromosomes in somatic and meiotic cells of Paris quadrifolia L.

\begin{tabular}{cccccc}
\hline Population no. & $\begin{array}{c}\text { Number of plants } \\
\text { containing } \\
\text { acc. chrom. }\end{array}$ & $\begin{array}{c}\text { Number of } \\
\text { examined }\end{array}$ & \multicolumn{2}{c}{ Number of acc. chrom. } \\
\cline { 5 - 6 } \cline { 5 - 6 } & plants & in root-tip cells & in PMC \\
\hline 3 & 3 & 200 & 0 & 10 \\
17 & 1 & 100 & 1 & 0 \\
19 & 1 & 100 & 0 & 2 \\
\hline
\end{tabular}

Table 3. No. of accessory chromosomes in PMC's from Pop. No. 3.

\begin{tabular}{cccc}
\hline Plant no. & $\begin{array}{c}\text { No. of cells } \\
\text { containing } \\
\text { acc. chrom. }\end{array}$ & $\begin{array}{c}\text { Highest no. } \\
\text { of acc. chrom. } \\
\text { in one cell }\end{array}$ & $\begin{array}{c}\text { Most common } \\
\text { no. of acc. } \\
\text { chrom. per cell }\end{array}$ \\
\hline 1 & 18 & 9 & 1 \\
2 & 12 & 10 & 1 \\
3 & 38 & 10 & 2 \\
\hline
\end{tabular}

The accessory chromosomes (f-group) were present in three populations. They were found in either or both meiotic and somatic cells. (Pop. 3, Tromsø, County of Troms, Pop. 17, Siljan, County of Telemark and Pop. 19, Fjelldalen, County of Telemark, ref. Table 1.)

In population No. 19 the number varied between two and zero in the PMC's (Fig. 1, A-B). In population No. 17, however, (Fig. 1C) a single accessory chromosome was found in some root-tip cells of one individual.

The accessory chromosomes of Paris quadrifolia differ markedly from the chromosomes belonging to the normal complement. Besides being much smaller (size 1-2 $\mu \mathrm{m}$ ) they are of globular shape and are usually heterochromatic. Their shape varies slightly between cells and different tissues. In PMC's in meiotic prophase (Fig. 2, A-D) condensed chromatin bodies are present outside the leptotene euchromosome group. These bodies, regarded as accessories, show sometimes by close microscopy a distinct differentiation in chromatids (ref. lower group, Fig. 2, D-E-I) clearly demonstrating their chromosomal nature. They are persistent 
in condensed state in later meiotic stages (Fig. 2, I-diplotene) and were not observed to split during meiotic divisions. Also in later meiotic stages they remained highly condensed (Fig. 1, A-B).

A similar behaviour was found in the root-tip cells. The accessory material remains condensed outside the interphase nucleus (Fig. 1C).

Numerical variations in the number of accessory chromosomes are present between different specimens in a single population (Table 2), as well as between different cells.

It is evident that accessory chromosomes are rarely occurring in Paris quadrifolia. They were found in only $1-3 \%$ of the analyzed specimens. We suggest, however, that it may be possible to relate very closely the origin of such accessories to the large structural changes observed in this species. This necessitates extensive cytological studies, including banding techniques. The extreme chromosome size in Paris quadrifolia thus represents an unusual potential for a close examination of the origin of accessory chromosomes. Further studies are thus in progress.

\section{Summary}

We report presence of accessory chromosomes in some populations of Paris quadrifolia L. In one population up to ten such chromosomes occurred in the PMC's. These chromosomes were also found occasionally in root tip cells, being condensed outside the nuclear membrane. The number of accessories varied both between meiotic and somatic cells.. Paris quadrifolia L. is a species well-known for its particular large chromosomes. The extensive structural differences of karyotypes between different populations in Norway might give interesting clues to the origin of accessories.

\section{Literature cited}

Battaglia, E. 1964. Cytogenetics of B-chromosomes. Caryologia 17: 245-299.

Darlington, C. D. 1941. Polyploidy, crossing-over, and heterochromatin in Paris. Ann. Bot. 5: 203-216.

Dyer, A. F. 1979. Investigation Chromosomes. London, Arnold. 138 p.

Geitler, L. 1937. Cytogenetische Untersuchungen an natürlichen Populationen von Paris quadrifolia. Zeitschr. f. ind. Abst. und Vererbgsl. 73: 182-197.

- 1938. Weitere cytogenetische Untersuchungen an natürlichen Populationen von Paris quadrifolia. Zeitschr. f. ind. Abst. und Vererbgsl. 75: 161-190.

Håkansson, A. 1945. Überzählige Chromosomen in einer Rasse von Godetia nutans Hiorth. Bot. Notis. 1: 1-19.

Huskins, C. L. and G. B. Wilson. 1938. Probable causes of the changes in direction of the major spiral in Trillium erectum. Ann. Bot., n.s. 2: 281-292.

Jones, K. 1978. Advances in Botanical Research. Ed. A. Woolhouse, Acad. Press London. Vol. 6, pp. 120-194.

Jones, R. N. 1975. B-chromosome systems in flowering plants and animal species. Intern. Rev. Cytol. 40: 1-100.

Müntzing, A. 1945. Cytological studies of extra fragment chromosomes in rye II. Transmission and multiplication of standard fragments and isofragments. Hereditas 31 : $457-477$.

- 1974. Accessory chromosomes. Ann. Rev. of Gen. 8: 243-266. 
Rees, H. 1974. B-chromosomes, Sci. Prog,, Oxf. 61: 535-554.

Vosa and Barlow 1972. Meiosis and B-chromosomes in Listera ovata (Orchidaceae). Caryologia 25: 1-8. 